\title{
STRENGTH EVALUATION OF COLD-FORMED STEEL COLUMNS USING THE RESULTS OF FINITE STRIP AND FINITE ELEMENT LINEAR STABILITY ANALYSIS
}

\author{
Luís C. Prola ${ }^{1}$, Igor Pierin ${ }^{2}$ \\ ${ }^{1}$ Polytechnic Institute of Tomar, Estrada da Serra, 2300-313, Tomar, Portugal \\ E-mail: luis.prola@ipt.pt \\ ${ }^{2}$ Polytechnic School of University of Sao Paulo, Av. Prof. Almeida Prado, trav 2, 271, \\ 05508-900, São Paulo,Brazil,e-mail: igor.pierin@poli.usp.br
}

Received 25 March 2009; accepted 23 April 2009

\begin{abstract}
Most cold-formed steel columns display open and rather thin-walled cross-sections which mean that their structural behaviour is strongly affected by local and global buckling. The local mode, that occurs for shorter profiles, is characterized by (i) the local plate mode (LPM) characterized by the simultaneous flexural buckling of the web and flanges and (ii) by the distortional mode (DM) characterized by the displacements of flange-stiffener edges (that remain plane). The global mode occurring for long profiles is characterized by (i) the flexural mode (FM) characterized by the translation of the whole section in the direction of the major principal axis and (ii) by the flexural-torsional mode (FTM) characterized by the simultaneous translation and rotation of the whole section. The possibility of using the results of linear stability analysis in the national codes of thin-walled cold-formed steel structural elements (for instance, European and Brazilian Codes) arises, i.e. local and global buckling instability modes and corresponding bifurcation stresses determining the ultimate strength of members. Two powerful numerical methods are chosen to perform a linear stability analysis of a cold-formed steel structural member: (i) the Finite Strip Method, $\left(i_{1}\right)$ the Semi-Analytical Finite Strip Method (trigonometric functions are used in the approximation of displacement) used for simply supported boundary conditions, $\left(\mathrm{i}_{2}\right)$ the Spline Finite Strip Method ('spline' functions are used in the approximation of displacement) used other boundary conditions and (ii) the Finite Element Method. The linear local and global stability results of for $\mathrm{Z}, \mathrm{C}$ and rack cold-formed columns are used to obtain ultimate strength through the procedures adopted in the Eurocode 3, Part 1.3 and in the Brazilian Code (NBR 14.762/2001). The obtained numerical estimates by specifications are compared with experimental results available in literature
\end{abstract}

Keywords: cold-formed, finite strip, finite element, local buckling modes, global buckling modes, code specifications.

\section{Introduction}

Most cold-formed steel profiles display open and rather thin walled cross-sections which mean that their structural behavior is strongly affected by local and global buckling. The local mode, which occurs for shorter bars, involves plate deformations (remain your axis in original configuration). Local modes can be characterized by (i) the local plate mode ( $L P M)$ that involves only the flexural deformations of the web and flange and (ii) the distortional mode $(D M)$ that includes the displacements of flange-stiffener edges remaining plane. The global mode occurring for long profiles is characterized by axis deformations. The global mode can be characterized by (i) the flexural mode $(F M)$ that involves the translation of the whole section in the direction of the major principal axis and (ii) the flexural-torsional mode (FTM) that occurs in the translation and rotation of the whole section. The aim of this article is (i) to present the numerical procedures based on Finite Strip and Finite Element in order to perform the stability analysis of thin-walled profiles and (ii) to study the ultimate strength of $Z, C$ and rack cold-formed columns 
by means of the results of linear stability analysis illustrated in Figure 1.

The buckling modes of cold-formed profiles with $Z$ cross-sections with inclined stiffeners are shown in Figure 2: (i) $L P M$ (Figure 2a), (ii) $D M$ (Figure 2b) and (iii) $F M$ in the direction of the minor principal axis (Figure 2c).

Figure 3 shows buckling modes that occur in the behavior of $C$ columns. Local modes are similar to $Z$ sections (Figure 2a, b). The global mode in section $C$ is FTM (Figure 3c). Figure 4 shows rack buckling modes: (i) the local plate mode ( $L P M$ - Figure $4 \mathrm{a})$ caused for web buckling, (ii) the distortional mode ( $D M$ - Figure 4b) involving horizontal and vertical stiffeners and (iii) the flexural-torsional mode (FTM - Figure 4c).

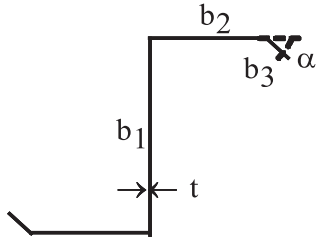

(a)

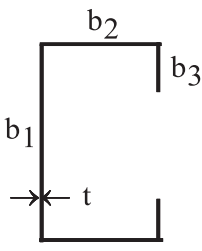

(b)

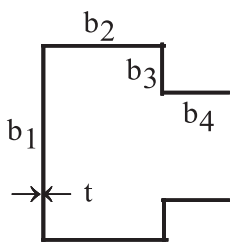

(c)

Fig. 1. Sections (a) in $Z$, (b) in $C$ and (c) in rack

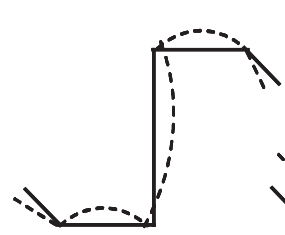

(a)

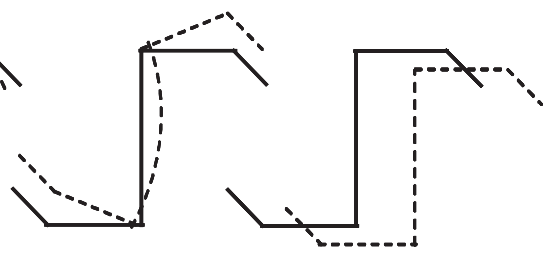

(b)

(c)
Fig. 2. Buckling modes of $\mathrm{Z}$ sections: (a) LPM (b) DM (c) FM

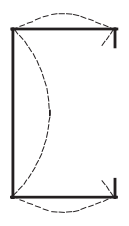

(a)

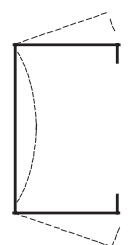

(b)

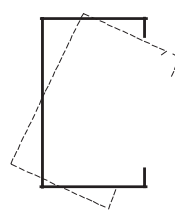

(c)
Fig. 3. Buckling modes of $C$ sections:

(a) LPM (b) DM (c) FTM (a)

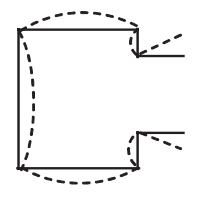

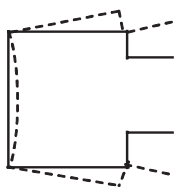

(b)

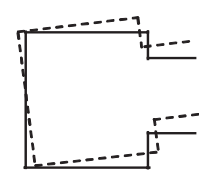

(c)
Fig. 4. Buckling modes of rack sections: (a) $L P M($ b) $D M$ (c) FTM
Linear Stability Analysis is carried out by computational programs developed by the authors of this paper: (i) the Finite Strip Method where the results were obtained by two computer programs developed by Prola (2001): $\left(i_{1}\right)$ the Semi-Analytical Finite Strip Method (trigonometric functions are used in the approximation of displacement) used for simply supported boundary conditions, $\left(\mathrm{i}_{2}\right)$ the Spline Finite Strip Method ('spline' functions are used in the approximation of displacement) used for other boundary conditions and (ii) the Finite Element Method where the results are obtained by a computer program developed by Pierin (2005).

The linear local and global stability results of $Z, C$ and rack cold-formed columns are used to obtain ultimate strength through the procedures adopted in the Eurocode 3, Part 1.3 (European Committee... 1996), the North-American Code (American Iron... 1997), the Brazilian Code (Associação... 2001) and the Direct Strength Method (DSM) (American Iron... 2004). The obtained numerical estimates by specifications are compared with experimental results available in literature.

\section{Linear Stability Analysis}

The methods of Finite Strip and Finite Element were developed by the authors to perform Linear Stability Analysis (LSA).

\subsection{The Finite Strip Method}

The Finite Strip Method (FSM), which constitutes a modification of the Finite Element Method (FEM), is particularly advantageous for application to structures with regular geometric configurations, simple boundary conditions and applied loads. The subdivision of the structure in 'finite' strips presupposes $(i)$ that its geometry remains unaffected in the longitudinal direction (e.g., prismatic bars) and (ii) knowledge of a function that approximates the longitudinal variation of the field of displacements with great precision and simultaneously satisfies respective boundary conditions. Figure 5 illustrates, for the case of a thin-walled profile $C$, the discretization of the structure in FSM.

The approach to the displacement field in each finite strip in the longitudinal direction is made through (i) polynomials that assure compatibility among the strips in the traverse direction and (ii) continuous functions (typically, trigonometric functions) that have to satisfy boundary conditions. Analytic solutions that supply the real configuration of the modes of instability can be frequently used as longitudinal functions. 


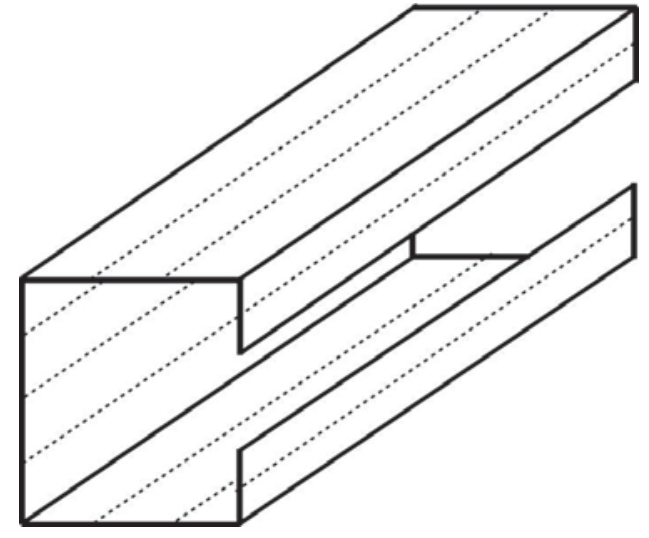

Fig. 5. Discretization in FSM

Due to this fact, the method is called the semi-analytic finite strip method. As mentioned above, in the traverse direction, the field of displacements is approximated in each finite strip for polynomials the degree of which is conditioned by compatibility among adjacent strips.

In spite of its usefulness and efficiency, computational FSM presents the important limitation of easily applicable to simply supported boundary conditions (local and global displacements). To overcome this limitation, Lau and Hancock (1998) developed an alternative formulation of the method of finite strips where the longitudinal variation of the field of displacements is approximated by a linear combination of special functions designated by $B_{3}$-Spline the properties of which allow simulating different boundary conditions and loads.

The use of functions $B_{3}$-Spline implies dividing each line nodal in several stations (Figure 6), which, logically, significantly increases the number of the degrees of freedom in the bar, and thus approximates FSM of FEM. However, a comparative analysis of applying the before mentioned two methods indicates that the incorporation of functions $B_{3}$-Spline in the formulati-

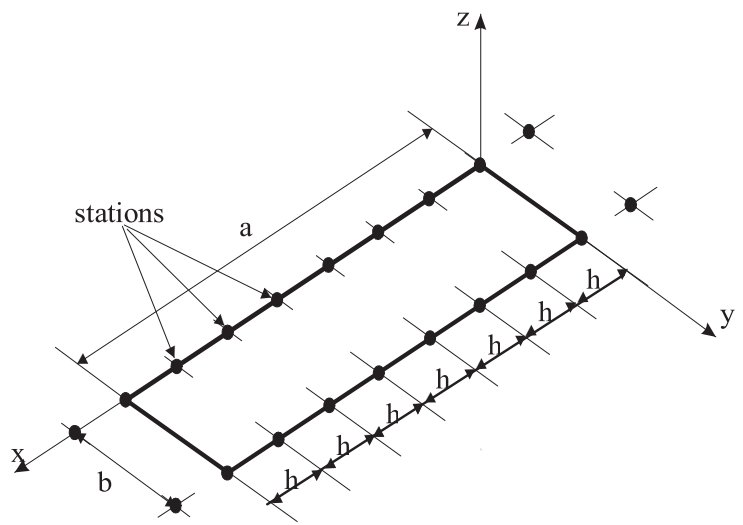

Fig. 6. Stations in SFSM on of FSM (now called the spline finite strip method $S F S M$ ) leads to a larger computational efficiency in relation to FEM (Hancock 1998).

The formulation of each finite strip (FSM and SFSM) involves the following steps:

(i) The identification of the degrees of freedom and the choice of approximation functions for membrane and flexure displacements.

(ii) A definition of deformation-displacement (cinematic) relationships.

(iii) Stress-deformation (constitutive) relationships.

(iv) Determination by means of the potential energy minimization or the principle of the virtual work of the equilibrium equations.

Figure 7 shows, respectively, the degrees of freedom in a semi-analytic finite strip and displacements with functions $B_{3} S$ (in this case, the degrees of freedom are, in fact, the coefficients of functions). Each strip has length $a$, width $b$, thickness $t$ and is delimited by nodal lines $i$ and $j$. It is observed that, in the first case, eight degrees of freedom exist (four for line nodal): (i) longitudinal displacements (membrane) $u_{i}$ and $u_{j}$, (ii) lateral displacements (membrane) $v_{i}$ and $v_{j}$, (iii) transverse displacements (flexural) $w_{i}$ and $w_{j}$ and (iv) rotations (flexural) $\theta_{i}$ and $\theta_{j}(\theta \equiv \partial w / \partial y)$. In the second case, $8(m+3)$ the degrees of freedom (half in each line nodal) allowing to obtain correspondents $u, v, w$ and $\theta$ in each one of the $(m+3)$ stations are located in each line nodal.

In the lateral direction of each finite strip (axis $y$ ), the displacements are approximate for the polynomials of (i) one degree (membrane displacements $u$ and $v$ ) and (ii) three degrees (flexural displacements $w$ and $\theta$ ). For a given value of $x$ :

$\left\{\begin{array}{l}u(x, y) \\ v(x, y)\end{array}\right\}=\left[N_{m}(y)\right]\left[\psi_{m}(x)\right]\left\{\delta_{m}\right\}$,

$w(x, y)=\left[N_{f}(y)\right]\left[\psi_{f}(x)\right]\left\{\delta_{f}\right\}$,

where (see in Prola 2001):

(i) $N_{m}$ and $N_{f}$ are one degree (membrane displacements) and three (flexural displacements) degrees polynomials, respectively.

(ii) $\psi_{m}$ e $\psi_{f}$ are trigonometric functions (for FSM) or functions $B_{3} S$ (for SFSM).

To satisfy boundary conditions in the end of each nodal line, it is necessary to define modified functions $B_{3} S$ obtained through a procedure presented in Prola (2001). 


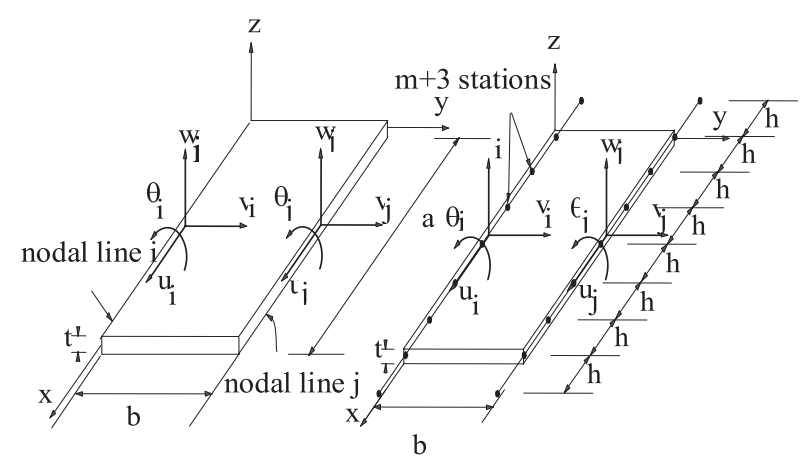

Fig. 7. Degrees of freedom: finite strip (a) semi-analytic (b) and having functions $B_{3} S$

The equilibrium equations of a finite strip are found by means of applying the Minimum Potential Energy Principle following the definition of stressstrain (Hooke law's) and strain-displacement relationships.

The coordinates, transformation and assemblage of matrixes lead to the equilibrium equations of the structural element, given by:

$([K]+\lambda[G])\{\delta\}=\{0\}$,

where $[K]$ and $[G]$ are the stiffness and geometric matrix of the structural element (bar), $\{\delta\}$ is the displacement vector (eigenvector) and $\lambda$ (eigenvalue) is parametric stress.

Equation (3) constitutes a problem of eingenvalues and eigenvectores the resolution of which supplies (i) the values of bifurcation stress and (ii) respective instability mode configuration. The Subspace Method (Bathe 1998) and LAPACK (Anderson et al. 1999) routines are used to solve this problem.

Two computer programs developed by Prola (2001) are used for obtaining the results given by the Finite Strip Method (FSM and SFSM).

\subsection{The Finite Element Method}

The application of FEM leads to an eigenvalue problem similar to equation (3). In fact, the structural element is divided in finite elements (elements with simple geometries and linked to each other by nodes). Inside the finite element, the field of displacements is approximated by a linear combination of functions usually polynomials the coefficients of which are nodal displacements.

Figure 8 shows the element discretization of column $C$ in FEM. Besides the transversal direction, the element is divided in the longitudinal one. (see difference with FSM in comparison with Figure 5).

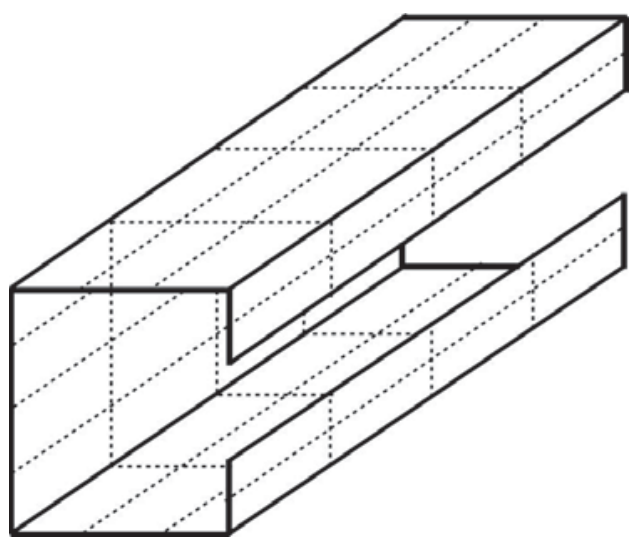

Fig. 8. Discretization in FEM

Pierin (2005) used four nodes shell element to perform linear stability analysis of thin-walled crosssections in the corner of which (i.e. web-flange edge), in order to become compatible, rotations between elements in different planes and the sixth degree of free$\operatorname{dom}\left(\theta_{z}\right)$ with null stiffness are included in each node. The finite element has 24 degrees of freedom ( 3 translations and 3 rotattions per node).

A four nodes quadrilateral finite element based on Discrete Kirchhoff Theory (DKQ) (Batoz, Tahar 1982) is developed without the consideration of shear deformation at discrete points on the sides of the element.

Each node has one transversal displacement $w$ and two rotations about $x$ and $y$.

$\theta_{x}=\partial w / \partial y$ and $\theta_{y}=-\partial w / \partial x$

$\beta_{x}$ and $\beta_{y}$ are normal vector rotations about the planes of the plate parallel to planes $x-z$ e $y-z$, respectively, defined by cubic incomplete polynomial:

$\beta_{x}=\sum_{i=1}^{8} N_{i} \beta_{x i}$

$\beta_{y}=\sum_{i=1}^{8} N_{i} \beta_{y i}$

where shape functions $N_{i}$ are the functions of eight nodes Serendipity element (Cook et al. 1989). The values of $\beta_{x i}$ and $\beta_{y i}$ are affected by corner nodes (externals) and intermediate nodes (internals) of the sides of $D K Q$ element (see Figure 8). For corner nodes (externals):

$\left\{\begin{array}{l}\beta_{x i}+w_{x i} \\ \beta_{y i}+w_{y i}\end{array}\right\}=\left\{\begin{array}{l}0 \\ 0\end{array}\right\} \quad$ for $\mathrm{i}=1,2,3,4$ 
and for intermediate nodes (internals):

$\beta_{s k}+w_{s k}=0 \quad$ for $\mathrm{k}=5,6,7,8$

where: $s$ - a parallel to the element side and $w_{s k}$ the derivation of traverse displacement $w$ in relation to $s$ in the intermediate node $k$ ( $w$ is defined by cubic expression along of the each side of the element):

$w_{s k}=-\frac{3}{2 l_{i j}}\left(w_{i}-w_{j}\right)-\frac{1}{4}\left(w_{s i}+w_{s j}\right)$,

where: $k=5,6,7,8$ is the intermediate node of sides $j=\overline{12}, \overline{23}, \overline{34}, \overline{41}$, respectively, and $l_{i j}$ is the length of the element side $i j$ (Figure 9).

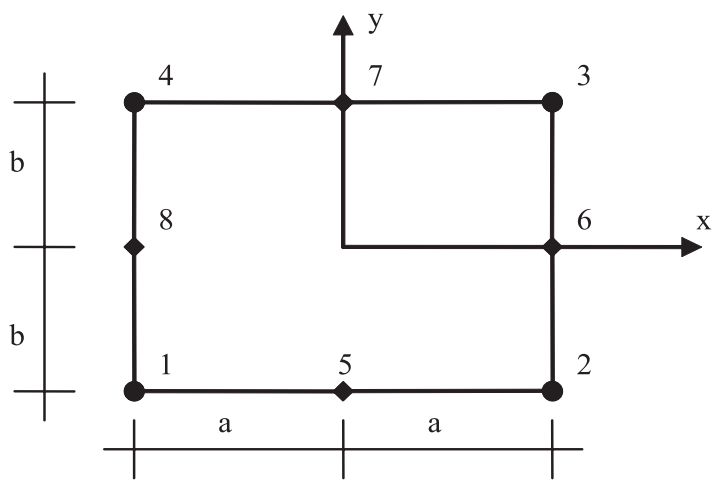

Fig. 9. Geometry of DKQ element

It is important to observe that: (i) displacement $w$ is not defined in the interior of the element and varies independently along of the side of the element; (ii) the Kirchhoff hypothesis is satisfied along of the boundary of the entire element ( $w_{s}$ and $\beta_{s}$ are quadratic expressions along of the sides); (iii) $D K Q$ element presents convergence for thin plate elements where shear effects are not important; (iv) DKQ element is compatible along the entire boundary.

The computer program implemented by Pierin (2005) is used for obtaining the results given by the Finite Element Method.

\section{Numerical Results of Linear Stability Analysis}

The curves represented in the next figures illustrate the variation of buckling coefficient $K_{b}$ with the element length/width ratio $\left(a / b_{1}\right)$ represented in the logarithmic scale for three types of columns displaying sections $C, Z$ and Rack. The buckling coefficient $K_{b}$ is related to column local (cross-section) critical bifurcation stress $\sigma_{b}$ by the expression:
$\sigma_{b}=\frac{K_{b} \pi^{2} E}{12\left(1-v^{2}\right)}\left(\frac{t}{b_{1}}\right)^{2}$,

where $E$ is the Young's modulus and $v$ is the Poisson coefficient.

\subsection{Sections $Z$ and $C$}

Figures 10 and 11 indicate the variation of the buckling coefficient vs. aspect ratio $a / b_{1}$ for columns $Z$ and $C\left(b_{2} / b_{1}=0.5\right.$ e $\left.b_{1} / t=50\right)$ where the buckling mode assumingly occurs with half sine wave $(n=1)$. Curves in Figures 10 and 11 show two local minima, the first of which corresponds to LPM (Figures 12 and 13) and the second one - to DM (Figures 14 and 15). The critical local buckling mode corresponds to the minor value of the two local minima. For long profiles $\left(a / b_{1}>10\right)$, the global mode (Figures 16 and 17$)$ is critical.

The observation of the curves for sections $Z$ and $C$ allows establishing the following comparisons: (i) local buckling behaviour ( $L P M$ and $D M$ ) is identical and (ii) the values of the global stress are slightly different, although they correspond to the buckling modes of distinct nature (FM for section C and FTM for section Z).

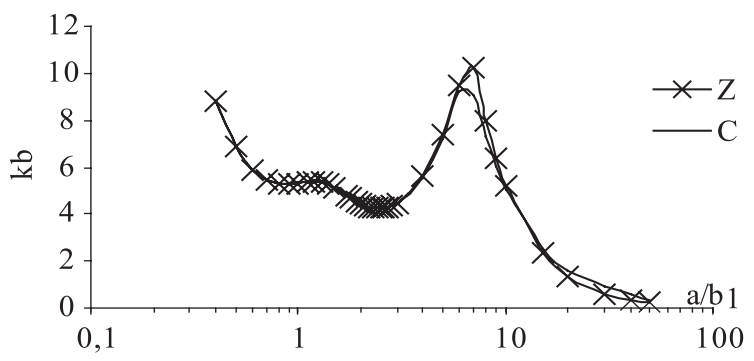

Fig. 10. Variation of $k_{b} v s$. $a / b_{1}$ for $b_{3} / b_{1}=0.07$

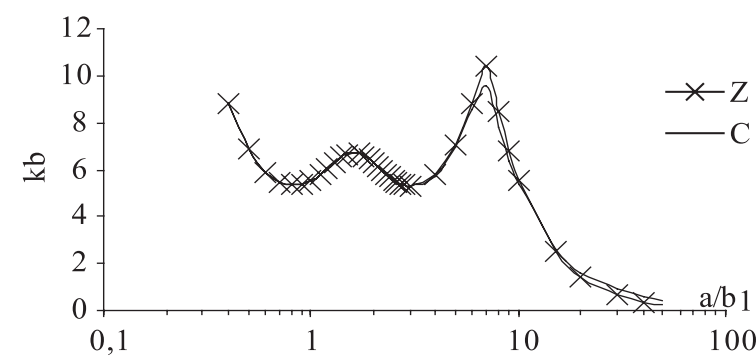

Fig. 11. Variation of $k_{b}$ vs. $a / b_{1}$ for $b_{3} / b_{1}=0.10$ 


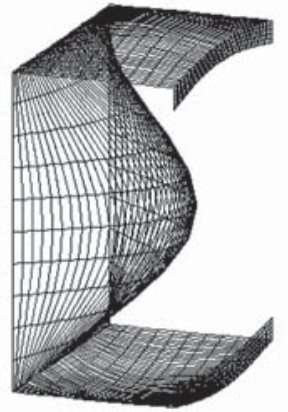

Fig. 12. The local plate buckling mode (LPM) of column C

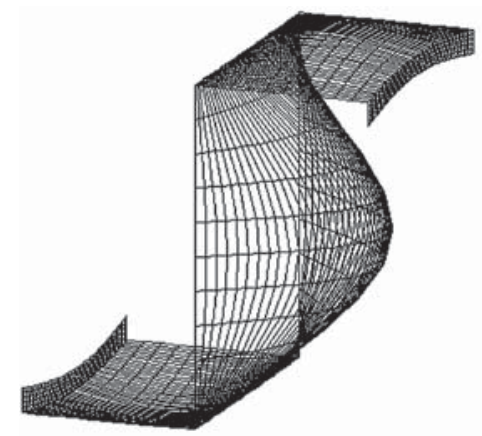

Fig. 13. The local plate buckling mode (LPM) of column $\mathrm{Z}$

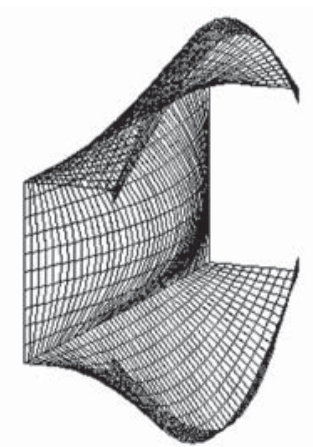

Fig. 14. The distortional buckling mode (DM) of column C

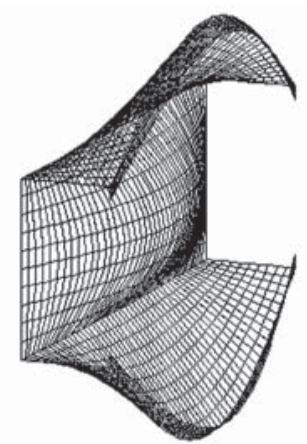

Fig. 15. The distortional buckling mode (DM) of column $\mathrm{Z}$

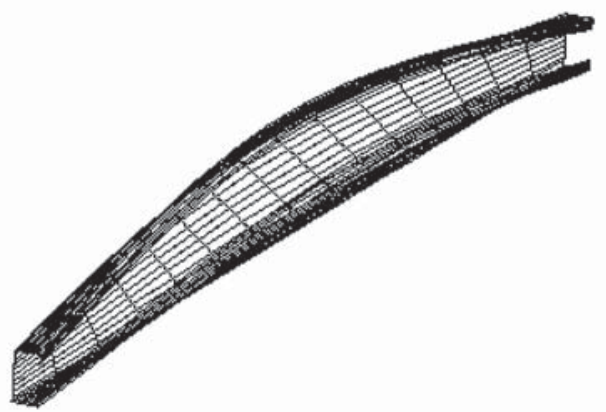

Fig. 16. The global flexural torsional buckling mode (FTM) of column C

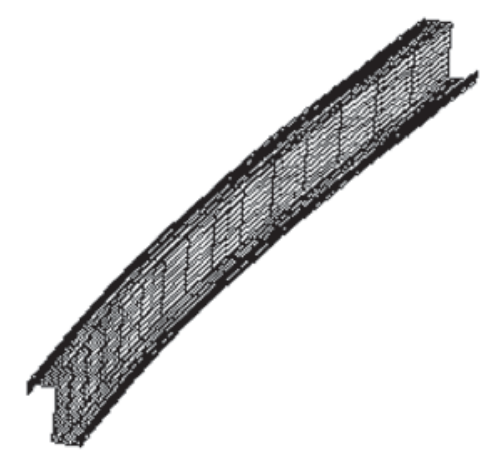

Fig. 17. The global flexural buckling mode (GFM) of column Z

\subsection{Rack Section}

Figure 18 shows the variation of the buckling coefficient vs. aspect ratio $a / b_{1}$ for rack columns with simply supported endings. Geometrical parameters for the rack column are: $b_{2} / b_{1}=0.5, b_{3} / b_{1}=0.2, b_{4} / b_{1}=$ 0.3 and $b_{1} / t=50$. Two methods including (i) $S F M$ and (ii) FEM were used. In case of the curve obtained with $S F M$, the buckling mode assumes a half sine wave and the curve has two local minima associated to the occurrence of $L P M$ (Figure 19) and DM (Figure 20). The critical local mode is $D M$ and, for long profiles, the global mode is FTM (Figure 20).

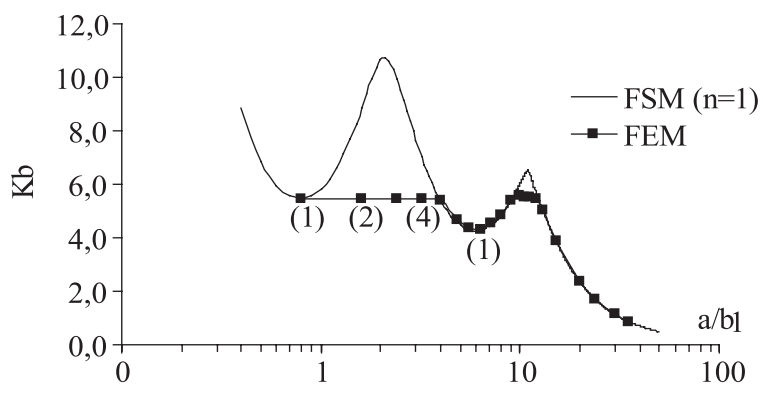

Fig. 18. The results of simply supported rack columns 


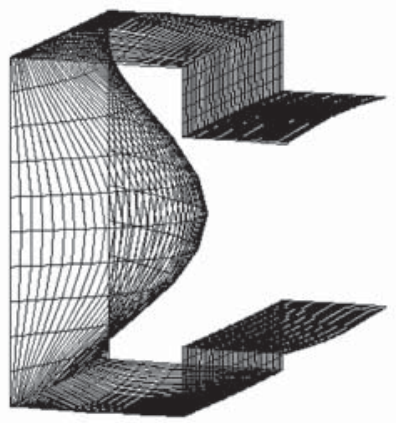

Fig. 19. The local plate buckling mode (LPM) of Rack column

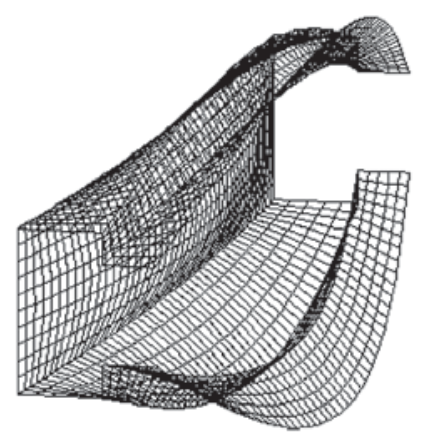

Fig. 20. The distortional buckling mode (DM) of Rack column

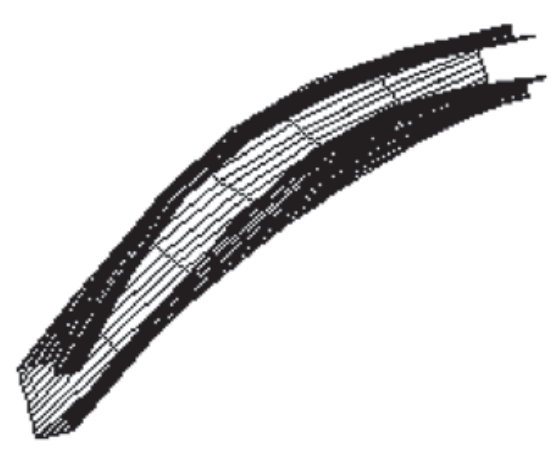

Fig. 21. The global flexural buckling mode (FTM) of Rack column

The curve carried out by FEM shows the critical buckling coefficient. For shorter profiles $\left(a / b_{1}<3.2\right)$, the buckling mode is $L P M$ and the number of the half sine wave (indicated in parenthesis) varies from 1 to 4 . For the values of $a / b_{1}$ between 3.2 and 12 , the buckling mode is $D M$ with a half sine wave. For long profiles $\left(a / b_{1}>12\right)$, FTM is critical. Transition between local and global modes occurs for columns with $a / b_{1} \approx 10$.

A comparison of the results between FEM and SFSM for the fixed column is presented in Figure 22. For both local modes (LMP and DM), critical buckling

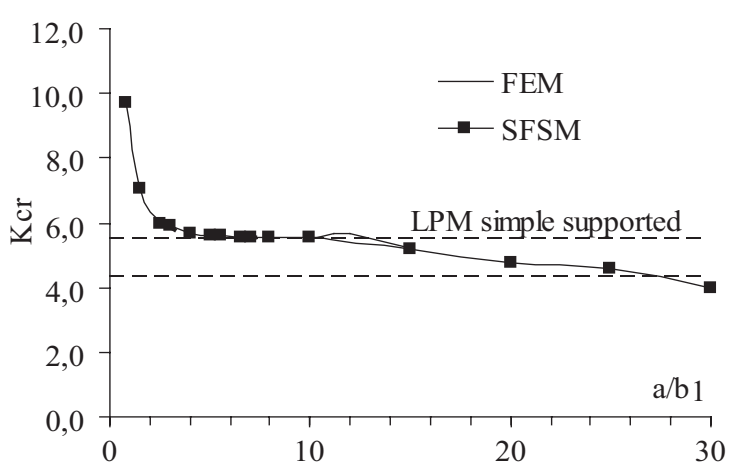

Fig. 22. The results of the fixed-end rack columns

coefficients are similar to those for simply supported columns. Boundary conditions for the columns only influence the results of the lower numbers of the half sine wave.

More information about the influence of fixing the warping and rotation of the boundary sections of the columns in the buckling coefficient can be found in Prola (2001). In case of the fixed columns, the critical buckling coefficient is not influenced by warping conditions for boundary sections. The fixed boundary condition is equivalent to restrict the warping of simply supported columns.

\section{Ultimate Strength Evaluation}

\subsection{The Direct Strength Method}

Schafer and Peköz (1998) proposed the Direct Strength Method $(D S M)$ as the alternative one to the Width Effective Method (WEM), a procedure used in several normative national codes for determining the ultimate strength of cold-formed profiles. The AISI (Associação... 2001) published the manual of coldformed projects using DSM.

The use of DSM (i) requires determining critical buckling loads by means of LSA and (ii) by means of a series of the curves of strength allows determining the ultimate strength of the profiles. Nominal ultimate strength due to local buckling $\left(P_{n l}\right)$ is given by (American Iron... 2004):

$P_{n l}=P_{n e} \quad$ for $\lambda_{l} \leq 0.776$

$P_{n l}=P_{n e} \cdot\left[1-0.15 \cdot\left(\frac{A_{g} \cdot \sigma_{c r l}}{P_{n e}}\right)^{0.4}\right]\left(\frac{A_{g} \cdot \sigma_{c r l}}{P_{n e}}\right)^{0.4}$ for $\lambda_{l}>0.77$

where $A_{g}$ is the cross section area, $\lambda_{l}$ is the reduced slender due to the local mode effects given by:

$\lambda_{l}=\sqrt{\frac{A_{g} \cdot \sigma_{c r l}}{P_{n e}}}$ 
being $\sigma_{c r l}$ critical local stress obtained from LSA and $P_{n e}-$ nominal ultimate strength for flexural, torsional and flexural-torsional buckling given by:

$P_{n e}=\left(0.658^{\lambda_{c}^{2}}\right) A_{g} f_{y} \quad$ for $\lambda_{c} \leq 1.5$

$P_{n e}=\left(\frac{0.877}{\lambda_{c}^{2}}\right) A_{g} f_{y} \quad$ for $\lambda_{c}>1.5$

where,

$\lambda_{c}=\sqrt{\frac{A_{g} \cdot f_{y}}{P_{e}}}$

in which $f_{y}$ is steel yielding stress and $P_{e}$ is minimum global elastic buckling load determined by:

$N_{E x}=\frac{\pi^{2} E I_{x}}{l^{2}}$

$N_{E y}=\frac{\pi^{2} E I_{y}}{l^{2}}$

$N_{\omega}=\frac{1}{r_{0}^{2}}\left(G I_{t}+\frac{\pi^{2} E I_{\omega}}{l^{2}}\right)$

being $E$ the modulus of elasticity, $I_{x}, I_{y}$ the moment of inertia about the centroid axis, $I_{t}$ the torsional constant, $G$ the shear modulus, $r_{0 x}, r_{0 y}$ asymmetrical parameters and $r_{0 x}$ the polar radius of gyration.

The nominal value of ultimate strength $\left(P_{n d}\right)$ corresponding to distortional buckling is given by:

$P_{n d}=A_{g} \cdot f_{y} \quad$ for $\lambda_{\text {dist }} \leq 0.561$

$P_{n d}=A_{g} \cdot f_{y}\left[1-0.25 \cdot\left(\frac{\sigma_{\text {dist }}}{f_{y}}\right)^{0,6}\right]\left(\frac{\sigma_{\text {dist }}}{f_{y}}\right)^{0,6}$ for $\lambda_{\text {dist }}>0.561$

where,

$\lambda_{\text {dist }}=\sqrt{\frac{\sigma_{\text {dist }}}{f_{y}}}$

and $\sigma_{\text {dist }}$ is critical distortional stress obtained from LSA.

\subsection{The Brazilian Code}

According to the Brazilian Code NBR 14.762/2001 (Associação... 2001), the nominal value of ultimate strength $\left(P_{n l}\right)$ due to local buckling is determined by:

$P_{n l}=\rho \cdot A_{e f} \cdot f_{y}$

where $A_{e f}$ is the effective area, $f_{y}$ is the steel yielding stress and $\rho$ is a reducing factor due to local buckling given by: $\rho=\frac{1}{\beta+\left(\beta^{2}-\lambda_{0}^{2}\right)^{0.5}} \leq 1.0$

$\beta=0.5\left[1+\alpha\left(\lambda_{0}-0.2\right)+\lambda_{0}^{2}\right]$,

with:

$\lambda_{0}=\sqrt{\frac{A_{e f} \cdot f_{y}}{P_{e}}}$

and $f_{y}$ is the steel yielding stress and $P_{e}$ is the minimal of critical elastic column buckling load determined by expression (14).

For flexural buckling, the initial imperfection parameter $\alpha$ depends on the geometry of the crosssection and the flexural axis found in Table 7 of the Brazilian Code (Associação... 2001). In case of flexural and torsional-flexural buckling, $\alpha=0.34$ must be adopted.

The nominal value of ultimate strength $\left(P_{n d}\right)$ due to distortional buckling is determined by:

$$
\begin{aligned}
P_{n d}= & A_{g} \cdot f_{y}\left(1-0.25 \cdot \lambda_{\text {dist }}^{2}\right) \quad \text { for } \lambda_{\text {dist }}<1.414 \\
P_{n d}= & A_{g} \cdot f_{y}\left[0.055 \cdot\left(\lambda_{\text {dist }}-3.6\right)^{2}+0.237\right] \\
& \text { for } 1.414 \leq \lambda_{\text {dist }} \leq 3.6
\end{aligned}
$$

\subsection{Eurocode 3- Part 1.3}

According to the Eurocode 3 (European Committee... 1996), the nominal value of the ultimate strength of the column $\left(P_{n}\right)$ is determined by:

$P_{n}=A_{e f f} F_{n}$

where $A_{\text {eff }}$ is the effective area of the cross-section and $F_{n}$ is nominal stress that corresponds to the collapse by global buckling:

$F_{n}=\chi \cdot f_{y}$

being $\chi$ a reducing factor for buckling resistance:

$\chi=\frac{1}{\phi+\left[\phi^{2}-\bar{\lambda}^{2}\right]^{0,5}} \leq 1,0$

and $\phi$ is given by:

$\phi=0,5\left[1+\alpha(\bar{\lambda}-0,2)+\bar{\lambda}^{2}\right]$.

Relative slenderness $\bar{\lambda}$ for the relevant buckling mode shall be determined from: 
$\bar{\lambda}=\left(f_{y b} / \sigma_{c r g}\right) \sqrt{\beta_{A}}$,

where $\sigma_{c r g}$ is the global critical stress and $\beta_{A}$ is a coefficient that relates to the effective area $\left(A_{\text {eff }}\right)$ and to the gross area $\left(A_{g}\right)$ of the cross-section. The $\alpha$ coefficient is named the imperfection parameter. For flexural instability, $\alpha$ (i.e. the dimension curve) depends on the geometry of the cross-section and the flexural axis found in Tables 6.1 and 6.2 of EC3 (European Committee... 1996).

The general method of EC3 to define the effective area is based on a structural analysis of the model showed in Figure 13 (a case of a simple stiffener) where rotation spring simulates restriction to rotation given for the web to the flange. For the distortional mode, the method defines a fictitious column supported in the elastic foundation the cross-section of which is the effective zone of the stiffener (area $A_{s}$ ) - see Figure 23. The translational rigidity of elastic foundation is defined here by $C_{z}$ (in $E C 3$, the assignment is ' $K$ ') and is supplied by the flexural of the flange in around of the web-flange junction.

The procedure of determining the effective area of the general method is described in the $\mathrm{PhD}$ thesis by Prola (2001).

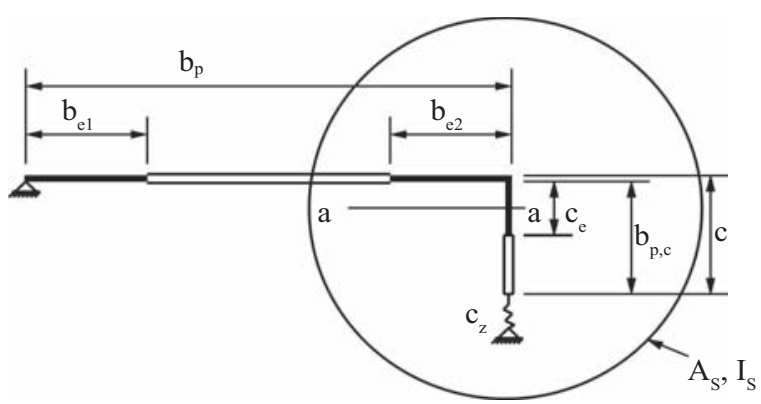

Fig. 23. Stiffener effective area and a 'fictitious column' supported in elastic foundation.

\section{Ultimate Strength}

Linear stability results for $Z, C$ and rack cold-formed columns are used to obtain the ultimate strength of these columns and are compared with experimental results available in literature. Ultimate strength is obtained by means of procedures adopted in the (i) Direct Strength Method (DSM) (America Iron... 2004), (ii) the North American Code (American Iron... 1997), (iii) the Eurocode 3, Part 1.3 (European Committee... 1996) and (iv) the Brazilian Code (Associação... 2001).

\subsection{Sections $Z$ and $C$}

Experimental work on $Z$ sections with the edges of sloping stiffeners was performed by Polyzois, Sudharmapal (1990) and Punardi et al. (1990). The authors carried out experiments on profiles with four lengths ( $a=457-914-1524-2438 \mathrm{~mm})$ and four angles of the stiffeners $\left(\alpha \approx 0^{\circ}-30^{\circ}-50^{\circ}-80^{\circ}\right)$.

Table 1 indicates that three different yielding stresses of steel $f_{y}=289.4-392.7-420.3 \mathrm{MPa}(E=$ $203 \mathrm{GPa}$ and $v=0.3$ ) were used. The ends of the columns were placed in direct contact with rigid plates in which a device was mounted to prevent lateral displacements. A system of spheres was placed in the external surface of these plates in order to permit the flexural rotation of the sections, and therefore to assure that the boundary condition of the column was simply supported (hinge).

Table 1 contains: (i) the local $\left(\sigma_{c r l}-L P M\right.$ or $\left.D M\right)$ and global $\left(\sigma_{c r g}-F M\right)$ buckling stress of all columns obtained from LSA and along with $\sigma_{c r}$, the buckling mode is indicated; (ii) the estimates of strength ultimate following the procedures adopted in the Eurocode 3- Part $1.3\left(P_{n E C 3}\right)$, in the Brazilian Code $\left(P_{n N}\right.$ $\left.{ }_{B R}\right)$, in the North-American Code $\left(P_{n A I S I}\right)$ and in the Direct Strength Method $\left(P_{n D S M}\right)$; (iii) the experimental values $\left(P_{\text {nexp }}\right)$ (the number in the parenthesis indicates the number of the carried out experiments). In $L S A$, columns were considered to be simply supported and restrained to warp at both ends.

The estimates obtained through EC3 are more conservative, whereas the other estimates (AISI, NBR and $D S M$ ), in some cases, exceed the experimental results of ultimate strength. The EC3 estimates are always the lowest values and, in general, the values obtained with DSM are the highest ones. In longer columns, where FTM is critical, all estimates are in a safety side in comparison with experimental results.

Experimental results for section $C$ with the stiffeners of slopping edges were obtained Young et al. (1999). They carried out 8 tests. All columns had the same geometry ( $a \approx 1504 \mathrm{~mm}, b_{1} \approx 97 \mathrm{~mm}$ and $b_{3} \approx$ $11 \mathrm{~mm})$. The columns were divided into two groups (C1 and $C 2$ ). Each group had four columns with a different angle of stiffeners $\left(\alpha \approx 30-45-60-90^{\circ}\right)$, thickness, flange width and the yielding stress $(C 1$ : $b_{1} / t \approx 50, b_{2} / b_{1} \approx 0.5$ and $f_{y} \approx 505 \mathrm{MPa} ; C 2: b_{1} / t \approx$ $40, b_{2} / b_{1} \approx 1$ and $f_{y} \approx 420 \mathrm{MPa}-E \approx 200 \mathrm{GPa}$ and $v$ $\approx 0.3$ for both groups). The geometrical characteristics, material proprieties and experimental value of ultimate strength for groups $C 1$ and $C 2$ are shown in 
Table 1. Analytical and experimental results $-Z$ sections

\begin{tabular}{|c|c|c|c|c|c|c|c|c|c|c|c|c|c|}
\hline $\begin{array}{c}\mathrm{b}_{1} \\
(\mathrm{~mm})\end{array}$ & $\mathrm{a} / \mathrm{b}_{1}$ & $\mathrm{~b}_{2} / \mathrm{b}_{1}$ & $\mathrm{~b}_{3} / \mathrm{b}_{1}$ & $\mathrm{~b}_{1} / \mathrm{t}$ & $\begin{array}{c}\alpha \\
\left({ }^{\circ}\right)\end{array}$ & $\begin{array}{c}\sigma_{\mathrm{crl}} \\
(\mathrm{MPa})\end{array}$ & $\begin{array}{c}\sigma_{\mathrm{crg}} \\
(\mathrm{MPa})\end{array}$ & $\begin{array}{c}\mathrm{f}_{\mathrm{y}} \\
(\mathrm{MPa})\end{array}$ & $\begin{array}{c}P_{n} \text { EXP } \\
(K N)\end{array}$ & $\begin{array}{c}P_{n \text { AISI }} \\
(\mathrm{KN})\end{array}$ & $\begin{array}{l}P_{n \text { EC3 }} \\
(\mathrm{KN})\end{array}$ & $\begin{array}{r}P_{n \text { NBR }} \\
(\mathrm{KN})\end{array}$ & $\begin{array}{r}P_{\text {n DSM }} \\
(\mathrm{KN})\end{array}$ \\
\hline 106.81 & 4.28 & 0.77 & 0.00 & 53.9 & 0.00 & $\begin{array}{c}93 \\
\text { LPM }\end{array}$ & 3102 & $\begin{array}{l}289.4 \\
392.7\end{array}$ & $\begin{array}{c}79.1(4) \\
110.8(2)\end{array}$ & $\begin{array}{c}91.6 \\
111.8\end{array}$ & $\begin{array}{l}79.1 \\
95.3\end{array}$ & $\begin{array}{c}93.16 \\
113.71\end{array}$ & $\begin{array}{c}87.38 \\
105.38\end{array}$ \\
\hline 98.88 & 4.62 & 0.63 & 0.20 & 49.3 & 29.0 & $\begin{array}{l}362 \\
\mathrm{DM}\end{array}$ & 3310 & $\begin{array}{l}289.4 \\
392.7\end{array}$ & $\begin{array}{l}109.6(4) \\
153.6(2)\end{array}$ & $\begin{array}{l}126.2 \\
147.5\end{array}$ & $\begin{array}{c}99.8 \\
123.0\end{array}$ & $\begin{array}{l}122.16 \\
150.98\end{array}$ & $\begin{array}{l}124.69 \\
150.32\end{array}$ \\
\hline 99.21 & 4.61 & 0.65 & 0.20 & 48.2 & 51.9 & $\begin{array}{c}425 \\
\text { LPM }\end{array}$ & 3330 & 289.4 & $153.7(4)$ & 140.3 & 118.5 & 145.62 & 149.54 \\
\hline 99.42 & 4.60 & 0.64 & 0.21 & 48.9 & 77.8 & $\begin{array}{c}404 \\
\text { LPM }\end{array}$ & 3247 & 289.4 & $151.5(3)$ & 140.7 & 130.6 & 146.30 & 145.44 \\
\hline 99.31 & 9.21 & 0.81 & 0.00 & 48.3 & 0.00 & $\begin{array}{c}103 \\
\text { LPM }\end{array}$ & 758 & 392.7 & $101.6(2)$ & 100.0 & 86.8 & 100.57 & 124.23 \\
\hline 99.16 & 9.22 & 0.64 & 0.20 & 48.2 & 33.0 & $\begin{array}{l}305 \\
\mathrm{DM}\end{array}$ & 837 & 392.7 & $145.2(2)$ & 142.7 & 114.3 & 145.30 & 144.85 \\
\hline 99.24 & 9.21 & 0.63 & 0.20 & 48.2 & 50.4 & $\begin{array}{c}419 \\
\text { LPM }\end{array}$ & 832 & 392.7 & $156.3(2)$ & 153.3 & 134.0 & 156.12 & 160.41 \\
\hline 99.26 & 9.21 & 0.64 & 0.21 & 48.2 & 78.1 & $\begin{array}{c}413 \\
\text { LPM }\end{array}$ & 814 & 392.7 & $152.9(2)$ & 160.7 & 140.2 & 161.30 & 161.18 \\
\hline 99.42 & 15.33 & 0.81 & 0.00 & 48.3 & 0.00 & $\begin{array}{c}104 \\
\text { LPM }\end{array}$ & 273 & 420.3 & 76.5 (2) & 77.7 & 68.8 & 78.43 & 93.63 \\
\hline 99.44 & 15.33 & 0.62 & 0.19 & 48.9 & 33.1 & $\begin{array}{l}305 \\
\mathrm{DM}\end{array}$ & 296 & 420.3 & $130.2(2)$ & 113.2 & 84.1 & 105.53 & 118.28 \\
\hline 99.49 & 15.32 & 0.63 & 0.20 & 49.0 & 49.0 & $\begin{array}{c}406 \\
\text { LPM }\end{array}$ & 300 & 420.3 & $133.1(2)$ & 119.3 & 95.7 & 107.61 & 120.27 \\
\hline 99.21 & 15.36 & 0.63 & 0.20 & 48.8 & 78.0 & $\begin{array}{c}404 \\
\text { LPM }\end{array}$ & 292 & 420.3 & $130.7(2)$ & 122.0 & 97.8 & 106.58 & 114.49 \\
\hline 99.82 & 24.43 & 0.80 & 0.00 & 51.7 & 0.00 & $\begin{array}{c}94 \\
\text { LPM }\end{array}$ & 109 & 289.4 & $47.6(2)$ & 36.8 & 34.9 & 37.24 & 47.99 \\
\hline 98.40 & 24.78 & 0.64 & 0.20 & 50.3 & 31.1 & $\begin{array}{l}237 \\
\mathrm{DM}\end{array}$ & 117 & 289.4 & $64.8(4)$ & 51.4 & 40.0 & 49.98 & 50.30 \\
\hline 99.87 & 24.42 & 0.62 & 0.19 & 51.7 & 50.0 & $\begin{array}{l}332 \\
\mathrm{DM}\end{array}$ & 117 & 289.4 & $64.3(2)$ & 50.8 & 44.5 & 45.36 & 47.27 \\
\hline 99.77 & 24.44 & 0.64 & 0.20 & 51.7 & 80.4 & $\begin{array}{c}361 \\
\text { LPM }\end{array}$ & 115 & 289.4 & $63.4(3)$ & 50.2 & 45.0 & 46.80 & 46.91 \\
\hline
\end{tabular}

Tables 2 and 3, respectively. The endings of the columns were placed in direct contact with rigid plates in order to restrain rotations in any axis (Young et al. 1999). In this way, the authors assured that, in extremity sections, (i) warping was restrained and (ii) local and global fixed condition was perfect.

The influence of changes in the centroid of the effective section (displacement in the direction of the symmetric axis) is considered in the procedure of EC3. This device transforms the column in a beamcolumn [1]. To evaluate the influence of this effect, in Tables 2 and 3, the estimates of the ultimate strength are included in parenthesis.

The experimental and numerical results presented in Tables 2 and 3 (relative to eight tests) show that the estimates obtained by means EC 3 and DSM are the lowest and the highest values, respectively. AISI and $D S M$ estimates never exceed the experimental results of group $\mathrm{Cl}$ and exceed all the tests of group C2. The Brazilian Code estimates are conservative in case of group $C 1$ and the results are very similar with the experimental results of group C2. Taking into account changes in the position of centroid, the numerical results of $E C 3$ are always conservative in comparison with the experimental ones. In fact, disregarding this effect, $P_{n E C 3}$ values are close to other estimates bearing in mind an exception it still leads low values from experimental results.

\subsection{Rack Sections}

Batista et al. $(1999,2001)$ carried out 32 buckling tests on rack columns. The conducted tests can be grouped into three categories ( $\mathrm{C} 1$ to $\mathrm{C} 3$ ).

All columns had the same cross-section defined by geometrical relations $b_{2} / b_{1}=0.6, b_{3} / b_{1}=0.2$ and $b_{4} / b_{1}=0.35$ (Figure 1c). The groups differ from each 
Table 2. Analytical and experimental results $-C$ sections $(C 1)$

\begin{tabular}{|c|c|c|c|c|c|c|c|c|c|c|c|c|}
\hline $\begin{array}{c}\mathrm{b}_{1} \\
(\mathrm{~mm})\end{array}$ & $a / b_{1}$ & $\mathrm{~b}_{2} / \mathrm{b}_{1}$ & $\mathrm{~b}_{3} / \mathrm{b}_{1}$ & $b_{1} / t$ & $\begin{array}{c}\alpha \\
\left({ }^{\circ}\right)\end{array}$ & $\begin{array}{c}\sigma_{\mathrm{crl}} \\
(\mathrm{MPa})\end{array}$ & $\begin{array}{c}\sigma_{\mathrm{crg}} \\
(\mathrm{MPa})\end{array}$ & $\begin{array}{l}P_{\text {n EXP }} \\
(\mathrm{KN})\end{array}$ & $\begin{array}{l}\mathrm{P}_{\mathrm{n} \text { AISI }} \\
(\mathrm{KN})\end{array}$ & $\begin{array}{l}\mathrm{P}_{\mathrm{n} \text { EC } 3} \\
(\mathrm{KN})\end{array}$ & $\begin{array}{c}\mathrm{P}_{\mathrm{n} N B R} \\
(\mathrm{KN})\end{array}$ & $\begin{array}{c}\mathrm{P}_{\mathrm{n} \text { DSM }} \\
(\mathrm{KN})\end{array}$ \\
\hline 7.5 & 5.4 & 0.52 & 0.11 & 52 & 31.2 & 230.6 & 645.3 & 117.5 & 103.4 & $\begin{array}{c}77.5 \\
(93.3)\end{array}$ & 101.03 & 110 \\
\hline 7.1 & 5.5 & 0.52 & 0.11 & 51 & 46.6 & 290.7 & 658.6 & 126.6 & 111.6 & $\begin{array}{c}75.3 \\
(102.4)\end{array}$ & 119.36 & 124.29 \\
\hline 7.3 & 5.4 & 0.52 & 0.11 & 51 & 60.7 & 332.3 & 669.0 & 139.1 & 114.5 & $\begin{array}{c}83.0 \\
(104.6)\end{array}$ & 131.37 & 132.76 \\
\hline 8.4 & 5.3 & 0.49 & 0.11 & 52 & 89.1 & 362.3 & 680.0 & 144.8 & 114.5 & $\begin{array}{c}90.0 \\
(104.1)\end{array}$ & 134.78 & 134.78 \\
\hline
\end{tabular}

Table 3. Analytical and experimental results $-C$ sections $(C 2)$

\begin{tabular}{|c|c|c|c|c|c|c|c|c|c|c|c|c|}
\hline $\begin{array}{c}\mathrm{b}_{1} \\
(\mathrm{~mm})\end{array}$ & $a / b_{1}$ & $\mathrm{~b}_{2} / \mathrm{b}_{1}$ & $\mathrm{~b}_{3} / \mathrm{b}_{1}$ & $\mathrm{~b}_{1} / \mathrm{t}$ & $\begin{array}{c}\alpha \\
\left(^{\circ}\right)\end{array}$ & $\begin{array}{c}\sigma_{\mathrm{crl}} \\
(\mathrm{MPa})\end{array}$ & $\begin{array}{c}\sigma_{\mathrm{crg}} \\
(\mathrm{MPa})\end{array}$ & $\begin{array}{l}P_{n \text { EXP }} \\
(\mathrm{KN})\end{array}$ & $\begin{array}{c}\mathrm{P}_{\mathrm{n} \text { AISI }} \\
(\mathrm{KN})\end{array}$ & $\begin{array}{c}\mathrm{P}_{\mathrm{n} \text { EC3 }} \\
(\mathrm{KN})\end{array}$ & $\begin{array}{l}P_{n \text { NBR }} \\
(\mathrm{KN})\end{array}$ & $\begin{array}{c}\mathrm{P}_{\mathrm{n} \text { DSM }} \\
(\mathrm{KN})\end{array}$ \\
\hline 96.6 & 15.6 & 1.0 & 0.12 & 40 & 28.6 & 119.0 & 501.8 & 127.9 & 149.1 & $\begin{array}{c}92.2 \\
(130.0)\end{array}$ & 126.97 & 131.49 \\
\hline 97.0 & 15.5 & 1.0 & 0.12 & 41 & 43.7 & 147.2 & 538.9 & 137.4 & 156.0 & $\begin{array}{c}95.0 \\
(135.0)\end{array}$ & 136.73 & 144.29 \\
\hline 96.8 & 15.5 & 1.0 & 0.12 & 41 & 60.4 & 176.5 & 545.3 & 149.0 & 160.1 & $\begin{array}{c}92.0 \\
(131.0)\end{array}$ & 146.11 & 157.39 \\
\hline 98.0 & 15.3 & 1.0 & 0.12 & 41 & 89.9 & 214.1 & 572.1 & 161.7 & 166.5 & $\begin{array}{c}95.0 \\
(134.6)\end{array}$ & 162.43 & 177.26 \\
\hline
\end{tabular}

other in the length and thickness of the walls and the yielding stress of the utilized steel $(E=205 \mathrm{GPa}$ and $v=0.3)$. Column lengths were chosen in a way of the buckling mode to always occur either in LPM (C1- 15 tests) or in $D M(C 1-10$ tests, $C 2-5$ tests and $C 3-$ 2 tests). The ending sections of the columns were (i) placed in direct contact with stiff plates $(\mathrm{C} 1-25$ tests and $C 2-5$ tests) or (ii) fixed in these plates $(C 3-2$ tests). In this case, the fixed condition was obtained by means of using composite laminated plates rigidly molded around the walls of the sections and consequently, placed in direct contacts with extremity plates. The global simply supported condition of the columns is obtained with spheres placed in the exterior faces of the extremity plates.

A direct contact between ending sections and extremity plates (i) partially restricted the rotation of the transversal edges of the walls, (ii) partially fixed warping and (iii) allowed some transversal displacement in the initial phase of loading. The numerical estimates consider the following cases: (i) the edges of the walls are fixed (C3) and (ii) extreme simply supported sections could not warp (C1 and $C 2)$.

Tables 4 and 5 show analytical (in terms of critical bifurcation stress, local, global, and ultimate strength estimates) and experimental results (ultimate strength) obtained from tested columns $C 1, C 2$ and $C 3$. For groups $C 1$ and $C 2$, two values of the local critical stress ( $L P M$ or $D M$ ) are calculated corresponding to simply supported columns with free (in the parenthesis) and fixed (in brackets) warping. The number of the halfwavelengths of buckling modes is placed along with the designation of the buckling mode. When the warping of simply supported columns is considered fixed, $L P M$ is critical. The experimental results of ultimate strength correspond to the medium values of the carried out tests the numbers of which are indicated in the parenthesis.

As $P_{n \text { NBR }}$ estimates depend on the nature of the critical buckling mode (MLP or MD), Table 4 shows different estimates of values for each critical mode. However, as $P_{n \text { DSM }}$ estimates depend on the value of the critical buckling stress, this table discloses different estimates for each critical stress value.

The estimates obtained from EC3 and presented in parenthesis were obtained without considering changes in the centroid of the effective section.

The results placed in Table 4 related to group C1 indicate that all analytical estimates are inferior to the received experimental results. EC3 estimates are always lower than AISI ones even when the warping of simply supported columns is considered fixed, $L P M$ is 
Table 4. Analytical and experimental results - rack sections (C1)

\begin{tabular}{|c|c|c|c|c|c|c|c|c|c|c|}
\hline $\begin{array}{c}\mathrm{b}_{1} \\
(\mathrm{~mm})\end{array}$ & $a / b_{1}$ & $\mathrm{~b}_{1} / \mathrm{t}$ & $\begin{array}{c}f_{\mathrm{y}} \\
(\mathrm{MPa})\end{array}$ & $\begin{array}{c}\sigma_{\mathrm{crl}} \\
(\mathrm{MPa})\end{array}$ & $\begin{array}{c}\sigma_{\mathrm{crg}} \\
(\mathrm{MPa})\end{array}$ & $\begin{array}{l}P_{\text {n EXP }} \\
(\mathrm{KN})\end{array}$ & $\begin{array}{c}\mathrm{P}_{\mathrm{n} \text { AISI }} \\
(\mathrm{KN})\end{array}$ & $\begin{array}{c}\mathrm{P}_{\mathrm{n} \text { EC3 }} \\
(\mathrm{KN})\end{array}$ & $\begin{array}{c}\mathrm{P}_{\mathrm{n} \mathrm{NBR}} \\
(\mathrm{KN})\end{array}$ & $\begin{array}{c}\mathrm{P}_{\mathrm{n} \text { DSM }} \\
(\mathrm{KN})\end{array}$ \\
\hline 127 & 2.43 & 58 & 294 & $\begin{array}{c}309 \\
(\mathrm{LPM}-3) \\
{[343]} \\
(\mathrm{LPM})(3)\end{array}$ & $-1^{(1)}$ & $\begin{array}{c}304 \\
(5)\end{array}$ & 230 & $\begin{array}{c}200 \\
(216)\end{array}$ & 236.31 & $\begin{array}{l}231.5 \\
239.5\end{array}$ \\
\hline 127 & 7.42 & 58 & 294 & $\begin{array}{c}227 \\
(\mathrm{DM}-1) \\
{[314]} \\
(\mathrm{LPM}-9)\end{array}$ & 8289 & $\begin{array}{c}276 \\
(4)\end{array}$ & 230 & $\begin{array}{c}200 \\
(216)\end{array}$ & $\begin{array}{l}183.53 \\
236.31\end{array}$ & $\begin{array}{l}182.4 \\
219.4\end{array}$ \\
\hline 127 & 2.44 & 50 & 311 & $\begin{array}{c}431 \\
(\mathrm{LPM}-3) \\
{[476]} \\
(\mathrm{LPM}-3)\end{array}$ & $-^{(1)}$ & $\begin{array}{l}324 \\
(5)\end{array}$ & 298 & $\begin{array}{c}264 \\
(283)\end{array}$ & 306.39 & $\begin{array}{l}310.4 \\
320.2\end{array}$ \\
\hline 127 & 6.86 & 50 & 311 & $\begin{array}{c}275 \\
(\mathrm{DM}-1) \\
{[436]} \\
(\mathrm{LPM}-8)\end{array}$ & 9720 & $\begin{array}{l}340 \\
(4)\end{array}$ & 298 & $\begin{array}{c}264 \\
(283)\end{array}$ & $\begin{array}{l}240.69 \\
306.39\end{array}$ & $\begin{array}{l}236.1 \\
295.5\end{array}$ \\
\hline 147 & 2.42 & 57 & 317 & $\begin{array}{c}322 \\
(\mathrm{LPM}-3) \\
{[359]} \\
(\mathrm{LPM}-3)\end{array}$ & $-^{(1)}$ & $\begin{array}{l}380 \\
(5)\end{array}$ & 339 & $\begin{array}{c}278 \\
(310)\end{array}$ & 344.44 & $\begin{array}{l}336.3 \\
348.6\end{array}$ \\
\hline 147 & 6.82 & 57 & 317 & $\begin{array}{c}232 \\
(\mathrm{DM}-1) \\
{[328]} \\
(\mathrm{LPM}-9)\end{array}$ & 9460 & $\begin{array}{c}376 \\
(2)\end{array}$ & 339 & $\begin{array}{c}278 \\
(310)\end{array}$ & $\begin{array}{l}261.37 \\
344.44\end{array}$ & $\begin{array}{c}260.7 \\
321\end{array}$ \\
\hline
\end{tabular}

(1) The global critical stress value is higher $\left(\sigma_{\mathrm{crg}}>75000 \mathrm{MPa}\right)$ and do not influence the $P_{n}$ value

Table 5. Analytical and experimental results - rack sections (C2 and C3)

\begin{tabular}{|c|c|c|c|c|c|c|c|c|c|c|c|}
\hline Group & $\begin{array}{c}\mathrm{b}_{1} \\
(\mathrm{~mm})\end{array}$ & $\mathrm{a} / \mathrm{b}_{1}$ & $\mathrm{~b}_{1} / \mathrm{t}$ & $\begin{array}{c}f_{y} \\
(\mathrm{MPa})\end{array}$ & $\begin{array}{c}\sigma_{\mathrm{crl}} \\
(\mathrm{MPa})\end{array}$ & $\begin{array}{c}\sigma_{\mathrm{crg}} \\
(\mathrm{MPa})\end{array}$ & $\begin{array}{c}P_{\text {n EXP }} \\
(\mathrm{KN})\end{array}$ & $\begin{array}{l}\mathrm{P}_{\mathrm{n} \text { AISI }} \\
(\mathrm{KN})\end{array}$ & $\begin{array}{c}\mathrm{P}_{\mathrm{n} E C 3} \\
(\mathrm{KN})\end{array}$ & $\begin{array}{c}\mathrm{P}_{\mathrm{n} \mathrm{NBR}} \\
(\mathrm{KN})\end{array}$ & $\begin{array}{c}\mathrm{P}_{\mathrm{n} \text { DSM }} \\
(\mathrm{KN})\end{array}$ \\
\hline $\mathrm{C} 2$ & 137 & 12.5 & 60 & 362 & $\begin{array}{c}213 \\
\mathrm{DM}(2) \\
{[299]} \\
\mathrm{DM}(2)\end{array}$ & 3316 & $230(3)$ & 293 & $\begin{array}{c}226 \\
(257)\end{array}$ & $\begin{array}{l}214.9 \\
260.6\end{array}$ & $\begin{array}{l}222.4 \\
258.9\end{array}$ \\
\hline $\mathrm{C} 2$ & 137 & 18.2 & 60 & 362 & $\begin{array}{c}215 \\
\operatorname{DM}(3) \\
{[255]} \\
\operatorname{DM}(2)\end{array}$ & 524 & $222(2)$ & 232 & $\begin{array}{c}182 \\
(203)\end{array}$ & $\begin{array}{l}216.4 \\
241.1\end{array}$ & $\begin{array}{l}223.4 \\
241.5\end{array}$ \\
\hline C3 & 137 & 12.5 & 60 & 362 & $\begin{array}{c}299 \\
\operatorname{DM}(2)\end{array}$ & 3316 & $258(1)$ & 293 & $\begin{array}{c}236 \\
(260)\end{array}$ & 260.6 & 258.9 \\
\hline C3 & 137 & 18.2 & 60 & 362 & $\begin{array}{c}255 \\
\mathrm{DM}(2)\end{array}$ & 524 & $220(1)$ & 232 & $\begin{array}{c}182 \\
(203)\end{array}$ & 241.5 & 241.5 \\
\hline
\end{tabular}

critical. The results obtained from $N B R$ and $D S M$ are quite similar and higher than those of EC3 when warping is taken as fixed.

The numerical results presented in Table 5, concerning groups $C 2$ and $C 3$ show that (i) AISI estimates are always greater than experimental results, (ii) EC3 estimates are lower than experimental results when changes in the position of the centroid are taken into account (on the another hand, when changes in the position of the centroid are not considered, some re- sults are not conservative) and (iii) some results of $N B R$ and DSM are higher than the experimental ones.

\section{Conclusions}

This paper initially presents a review of studies on buckling modes in the cold-formed steel columns. A brief description of Finite Strip and Finite Element Methods is formulated. The following four different methods of determining ultimate strength columns 
are described: (i) the Direct Strength Method (American Iron... 2004), (ii) the specifications of the Brazilian Code (Associação... 2001), (iii) the specifications of the European Code EC3 (European Committee... 1996) and (iv) North-American specifications (American Iron... 1997).

Linear Stability Analysis based on the Finite Strip Method and the Finite Element Method is then performed. These methods were computationally implemented by the authors and applied to analyze the columns of $C, Z$ and rack sections. The results of critical bifurcation stress and corresponding instability mode showed very good correlation between the methods.

The obtained numerical results along with four described different methods were used to estimate ultimate strength and then compared to the results of the experiments available in literature. An important point to be emphasized in this case is the advantages of having the computer method available to obtain critical buckling modes and stresses, in sense of applying the modern national codes of cold-formed steel structures.

Although the testing sample is limited and does not allow establishing definitive conclusions, the estimates of ultimate strength given by the Direct Strength Method, the Brazilian Code and the North-American Code exceed experimental values in some columns. The estimates given by the European Code are always on the safety side, whereas change in the position of the centroid of the effective section was taken into account as required by this code.

\section{References}

American Iron and Steel Institute (AISI) - The Specification for the Design of Cold-Formed Steel Structural Members, 1996. (Part V of "Cold-Formed Steel Design Manual", published in 1997).

American Iron Steel Institute (AISI) - "Attachment A, Appendix 1- Design of Cold-Formed Steel Structural Members Using Direct Strength Method", Specification for the Design of Cold-Formed Steel Structure Members, Washington, 2004.

Anderson, E.; Bai, Z.; Bischof, C.; Blackford, L. S.; Demmel, J.; Dongarra, J.; Croz, J. D.; Greenbaum, A.; Hammarling, S.; McKenney, A.; Sorensen, D. 1999. LAPACK User's Guide (3 ${ }^{\text {rd }}$ Edition), Society for Industrial and Applied Mathematics (SIAM).

Associação Brasileira de Normas Técnicas (ABNT), NBR 14762:2001, Dimensionamento de Estruturas de Aço Cons- tituídas por Perfis Formados a Frio - Procedimentos. Rio de Janeiro, 2001 (in Portuguese).

Bathe, K.-J. 1998. Finite Element Procedures. Prentice Hall, New Jersey, 1998.

Batista, E.; Camotim, D.; Prola, L. C.; Vazquez, E. 1999. Encurvadura Local de Colunas de Aço Enformadas a Frio com Secção em "Rack", in Construção Metálica e Mista 2 (Actas do $2^{\circ}$ Encontro Nacional de Construção Metálica, Coimbra). Eds. A. Lamas; L. Simões da Silva; P. Cruz, 401-412 (in Portuguese).

Batista, E.; Camotim, D.; Prola, L.C.; Vazquez, E. 2001. On the Influence of the End Plate Conditions on the Distortional Buckling of Cold-Formed Rack Sections, in Proceedings of 2000 Structural Stability Research Council Annual Technical Session and Meeting. Memphis, USA.

Batoz; J. L.; Tahar; M. B. 1982. Evaluation of a new quadrilateral thin plate bending element, International Journal for $\mathrm{Nu}$ merical Methods in Engineering 18: 1655-1677.

Cook, R. D.; Malkus, D. S.; Plesha; M. F. 1989. Concepts and applications of finite element analysis. John Wiley \& Sons Inc, $3^{\text {rd }}$ edition.

European Committee for Standardization - Eurocode 3: Design of Steel Structures, Part 1.3: General Rules - Supplementary Rules for Cold Formed Thin Gauge Members and Sheeting, ENV 1993-1-3, 1996.

Hancock, G. J. 1998. Finite Strip Buckling and Nonlinear Analyses and Distortional Buckling Analysis of Thin-Walled Structural Members, in Coupled Instabilities in Metal Structures: Theoretical and Design Aspects, Ed. J. Rondal, CISM Course No379, 225-289 (part V), Springer-Verlag, Wien.

Pierin, I. 2005. Stability Study of GFRP Pultruded Profiles. M Sc. Dissertation, Federal University of Santa Catarina, Brasil, 2005. (in Portuguese).

Polyzois, D.; Sudharmapal, A. R. 1990. Cold-Formed Steel Z-Sections with Sloping Edge Stiffeners under Axial Load, Journal of Structural Engineering (ASCE) 116(2): 392-406.

Prola, L. C. 2001. Local and Global Stability of Cold-Formed Steel Members. Ph.D Thesis, Civil Engineering Department, Technical University of Lisbon, Portugal (in Portuguese).

Punardi, R. W.; Tassoulas, J. L.; Polyzois, D. 1990. A Study of Cold-Formed Z-Section Steel Members under Axial Loading, in Proceedings of $10^{\text {th }}$ International Specialty Conference on Recent Research and Developments in Cold-Formed Steel Design and Construction, University of Missouri-Rolla, St. Louis, USA, 197-222.

Schafer, B. W.; Peköz, T. 1998. Direct Strenght Prediction of Cold-Formed Steel Members Using Numerical Elastic Buckling Solutions, in Thin-Walled Structures, Research and Development. Eds. Shanmugan, N. E.; Liew, J. Y. R. and Thevendran, V. Elsevier.

Young, B. ; Hancock, G. J. 1999. Compression Tests of ThinWalled Channels with Sloping Edge Stiffeners, in LightWeight Steel and Aluminium Structures (ICSAS'99). Eds. P. Mäkeläinen, P. Hassinen. Elsevier Applied Science, 45-52. 


\section{ŠALTAI FORMUOTU PLIENINIU KOLONU LAIKOMOSIOS GALIOS IVERTINIMAS NAUDOJANT BAIGTINIŲ STRYPŲ IR ELEMENTŲ TIESINIO PASTOVUMO SKAIČIAVIMO REZULTATUUS}

\section{C. Prola, I. Pierin}

Santrauka. Dauguma šaltai formuotų plieninių kolonų turi atvirus arba plonasienius skerspjūvius, todèl jų konstrukcinė elgsena daugiausia priklauso nuo vietinio arba bendrojo klupumo. Vietinis klupumas, kuris būdingas (1) trumpesniems profiliuočiams, gali būti apibūdinamas vietinès plokštelès modeliu (LPM), pasižyminčiu vienalaikiu lenkiamuoju juostų ir sienelių klupumu ir (2) iškraipomuoju modeliu (DM), kurị apibūdina juostų ir sąstandų kraštų (kurie išlieka plokšti) poslinkiai. Bendrasis klupumas, kuris būdingas ilgiems profiliuočiams apibūdinamas (1) lenkiamuoju modeliu (FM). Jam būdingas viso skerspjūvio išilgai pagrindinès ašies pasislinkimas ir (2) lenkiamasis sukamasis (FTM) modelis, kuris pasižymi viso skerspjūvio pasislinkimu ir pasisukimu. Nacionalinėse šaltai formuotų plonasienių plieninių elementų normose (taip pat Europos ir Brazilijos) yra galimybè taikyti tiesini pastovumo skaičiavimą, t. y. nustatant ribinę elemento laikomąją galią naudoti vietinio ir bendrojo klumpamojo nepastovumo modelius bei atitinkamus išsišakojimo įtempiu. Šaltai formuotų plieninių elementų tiesiniam pastovumui skaičiuoti pasirinkti du veiksmingi skaičiavimo metodai: 1 . Baigtinių strypų metodas: 1.1- pusiau analitinis baigtinių strypų metodas (trigonometrinès funkcijos naudojamos poslinkiui aproksimuoti), kuris taikomas lankstinio atrèmimo kraštinėmis sąlygomis; 1.2 - kreivinių baigtinių strypų metodas („kreivinès“ funkcijos naudojamos poslinkiui aproksimuoti), taikomas kitokiomis kraštinèmis sąlygomis. 2. Baigtinių elementų metodas. Z ir C skerspjūvių ir spragotųjų šaltai formuotų kolonų tiesinio vietinio ir bendrojo pastovumo rezultatai naudojami nustatyti ribinę laikomąją galią remiantis Eurokodo 3 (1.3 dalies) ir Brazilijos normų (NBR 14.762/2001) priimtomis metodikomis. Pagal instrukcijas gautieji skaitiniai įverčiai palyginti su literatūroje randamais eksperimentinių tyrimų rezultatais.

Reikšminiai žodžiai: šaltai formuotas, baigtinis strypas, baigtinis elementas, vietinio klumpamojo nepastovumo modelis, bendrojo klumpamojo nepastovumo modelis, normų reikalavimai. 